\title{
SISTEM INFORMASI PENDAFTARAN ONLINE ANGGOTA ASOSIASI PROGRAM STUDI INFORMATIKA PGRI JAWA TIMUR
}

\author{
Ahmad Bagus Setiawan' \\ Teknik Informatika, Universitas Nusantara PGRI Kediri \\ Jl. KH. Achmad Dahlan Gg. 1 Mooroto Kota Kediri \\ E-mail:ahmadbagus@unpkediri.ac.id
}

\begin{abstract}
Abstraks
Asosiasi Program Studi Informatika (APSI) PGRI Jawa Timur Merupakan Asosiasi yang didirikan oleh PGRI Jawa Timur untuk mengayomi Program Studi dalam bidang Informatika, dalam hal kerja sama antar lembaga diantaranya, penelitian, pengabdian masyarakat, sistem bembelajaran dan pelatihan. Dalam sistem pendaftaran Asosiasi ini, maka dibuatkan sebuah sistem pendaftaran berbasis online, dimana banyak Calon anggota asosiasi yang ingin mendaftarkan diri sebagai anggota APSI. Dengan adanya Sistem Informasi Pendaftaran Online ini,pendataan calon anggota Asosiasi lebih mudah dan dapat dikenali lebih rinci biodata dari calon anggota Asosiasi.
\end{abstract}

Kata Kunci: Sistem Informasi, Pendaftaran, APSI

\section{PENDAHULUAN}

\subsection{Latar Belakang}

APSI (Asosiasi Program Studi Informatika) merupakan sebuah Asosiasi dibawah PGRI Jawa Timur dimana para pengurus adalah dosen dari beberapa perguruan Tinggi PGRI Jawa Timur. Asosiasi ini masih tergolong baru karena terbentuk pada tahun 2015 dan dalam proses penggodokan program kerja.

Dalam perjalan waktu, maka diputuskan untuk membuat sebuah sistem untuk para calon anggota baru agar dengan mudah menerima informasi dan cara pendaftaran enjadi anggota Asosiasi program Studi Informatika PGRI Jawa Timur.

Dalam perancangan sistem hal yang pertama di canangkan adalah Sistem Pendaftaran Online Anggota Asosiasi Program Studi Informatika Pgri Jawa Timur. Supaya daya setiap anggota dapat diketahui secara pasti dan dapat dijadikan acuan untuk Program Kerja menyangkut Tri Dharma Perguruan Tinggi ( Pengajaran, penelitian, dan Pengabdian Masyarakat)

\subsection{Rumusan Masalah}

a. Bagaimana merancang sebuah Sistem Pendaftaran Online Anggota Asosiasi Program Studi Informatika Pgri Jawa Timur

b. Pendataan Calon anggota Asosiasi berdasarkan pendaftaran secara Online

\subsection{Tujuan Penelian}

1. Tujuan Umum.

Terealisasinnya Sistem Pendaftaran Online Anggota Asosiasi Program Studi Informatika Pgri Jawa Timur

2. Tujuan Khusus.
a. Membantu
Asosiasi Program Studi Informatika Untuk mendata Calon Anggota Baru.

b. Membantu Asosiasi Program Studi Informatika dalam penyampaian informasi.

c. Memberikan Informasi khusus untuk informasi penting.D

d. Dari kebutuhan dan permintaan informasi yang cepat, dan bias tersampaikan kepada Calon Anggota Asosiasi Program Studi Informatika.

\subsection{Batasan masalah.}

1. Penelitian dilakukan dalam lingkungan Asosiasi Program Studi Informatika.

2. Aplikasi ini digunakan untuk memberikan informasi secara cepat kepada calon anggota Asosiasi

3. Aplikasi ini berbasis website Sistem ini memberikan data Penyampaian akses informasi secara akurat

\section{PEMBAHASAN}

Metode Objek pada pada penelitian ini adalah Asosiasi Program Studi Informatika (APSI) PGRI Jawa Timur, dimana metode yang dilakukan dalam pengumpulan data adalah observasi dan studi pustaka dimana sistem yang dikembangkan menggunakan metode prototipe, Adapun langkah dalam prototipe dalam membangun aplikasi ini adalah sebagai berikut

\subsection{Sistem Informasi}

Sistem informasi (Information System) merupakan kombinasi teratur dari orang- orang perangkat keras (hardware), perangkat lunak (software), jaringan komunikasi, dan sumber daya data yang mengumpulkan, mengubah, dan menyebarkan informasi dalam sebuah organisasi. Orang tergantung pada sistem informasi untuk berkomunikasi antara satu sama lain dengan menggunakan berbagai jenis alat fisik, perintah dan prosedur pemrosesan informasi, saluran 
telekomunikasi atau jaringan, dan data yang disimpan atau sumber daya data.

Sistem informasi adalah suatu sistem di dalam suatu organisasi yang mempertemukan kebutuhan pengolahan data transaksi harian, mendukung operasi, bersifat manajerial dan kegiatan strategi dari suatu organisasi serta menyediakan pihak luar tertentu dengan laporanlaporan yang diperlukan.

\subsection{World Wide Web}

WWW atau World Wide Web maupun Web saja adalah sebuah sistem yang saling terkait dalam sebuah dokumen berformat hypertext yang berisi beragam informasi, baik tulisan, gambar, suara, video, dan informasi multimedia lainnya dan dapat diakses melalui sebuah perangkat yang disebut web browser.

Menterjemahkan dokumen hypertext kedalam bentuk dokumen yang dapat dipahami oleh manusia, maka web browser melalui web client akan membaca halaman web yang tersimpan di sebuah web server melalui protokol yang sering disebut HTTP atau Hypertext Transfer Protocol. Perangkat lunak web browser saat ini tersedia dalam berbagai produk dengan kelebihan dan kekurangannya masing-masing. Beberapa web browser yang paling terkenal saat ini adalah Mozilla Firefox, Internet Explorer, Opera, Google Chrome, Safari dan lain sebagainya Dokumen hypertext yang tersimpan didalam sebuah web server memiliki banyak link atau sambungan antara satu dokumen hypertext dengan dokumen hypertext lainnya. Dengan adanya link antar dokumen hypertext, maka hal tersebut dapat memudahkan pengakses untuk mengunjungi atau mendapatkan dokumen- dokumen terkait yang diinginkannya.

\subsection{PHP}

PHP merupakan singkatan dari PHP Hypertext Preprocessor. PHP digunakan sebagai bahasa script server-side dalam pengembangan Web yang disisipkan pada dokumen HTML. Penggunaan PHP memungkinkan Web dapat dibuat dinamis sehingga maintenance situs Web menjadi lebih mudah dan efisien. PHP ditulis menggunakan bahasa $\mathrm{C}$.

PHP memiliki banyak kelebihan yang tidak dimiliki oleh bahasa script sejenis. PHP difokuskan pada pembuatan script server-side, yang bisa melakukan apa saja yang dilakukan oleh CGI, seperti mengumpulkan data dari form, menghasil kan isi halaman web dinamis, dan kemampuan mengirim serta menerima cookies, bahkan lebih daripada kemampuan CGI.

PHP tidak terbatas pada hasil keluaran HTML (HyperText Markup Language). PHP juga memiliki kemampuan untuk mengolah gambar, file PDF, dan movie flash. PHP juga dapat menghasilkan teks seperti XHTML dan file XML lainnya. Salah satu fitur yang dapat diandalkan oleh PHP adalah dukungannya terhadap banyak database, salah satunya adalah MySQL.

\section{METODOLOGI PENELITIAN}

\section{a. Identifikasi kebutuhan.}

Pada tahap ini merupakan tahap analisis sistem kegiatan yang dilakukan adalah melakukan studi kelayakan dan studi terhadap kebutuhan Sistem pendaftaran Calon Anggota Asosiasi, dimana pendaftaran masih bersifat komunikasi antar pengurus dan calon anggota baru, dan tidak ada sistem yang mendata pendataran Calon anggota baru.

Dengan adanya permasalah tersebut maka, sistem yang lama dibuat sistem yang baru merencanankan perbaikan dan mem bangun sistem tersebut. Hal yang paling penting dalam tahap ini adalah proses pembanguna Infrastruktur sistem.

\section{b. Mengembangkan prototipe.}

Pada tahap ini membangun infrastruktur sistem, desain atau perancangan mengenai permodelan sistem. Desain tersebut nantinya akan diperlihatkan kepada pihak Asosiasi dan hasilnya akan ditentukan prototipe nya sesuai dengan kebutuhan, jika belum akan dilakukan perbaikan terhadap prototipe sistem tersebut.

\section{c. Menentukan prototipe dapat diterima}

Evaluasi ini dilakukan oleh pihak Pengurus asosiasi apakah prototipe yang sudah dibangun sudah sesuai dengan keinginan pengguna. Jika sudah sesuai maka langkah selanjutnya akan diambil. Jika tidak prototipe direvisi dengan mengulang langkah sebelumnya.

\section{d. Mengkodekan sistem}

Tahap dimana prototipe yang sudah di sepakati dibangun berbasis website dan diterjemahkan ke dalam bahasa pemrograman PHP .

\section{e. Menguji sistem}

Sistem sudah menjadi suatu perangkat lunak berbasis website dan akan diuji terlebih dahulu. Pengujian ini dilakukan dengan metode testing, karena pengujian ini tidak menekankan pada struktur aplikasi pengujian diinginkan dan mengetahui kesalahan tatapmuka, kesalahan dalam akses database .

\section{f. Menentukan jika sistem operasional dapat diterima.}

Pihak Asosiasi mengevaluasi sistem apakah sesuai dengan yang dinginkan. Jika sesuai, langkah selanjutnya dilakukan; jika tidak,maka akan kembali ke langkah sebelumnya. Sehingga sistem dapat disesuaikan dengan baik.

\section{g. Menggunakan sistem}

Sistem diuji dan diterima oleh pihak pengguna dan siap untuk digunakan dengan baik sesuai kebutuhan pengguna.

\section{h. Diagram Alir}

Pada tahap ini akan dipaparkan urutan langkahlangkah yang dibuat secara sistematis untuk 
menyelesaikan penelitian. Sebagaimana terdapat pada gambar dibawah ini.

Perancangan Data Flow Diagram (DFD) merupakan gambaran luas sistem yang diterapkan pada Sistem Informasi Pendaftaran Online Anggota Asosiasi Program Studi Informatika Pgri Jawa Timur,

Dimana Calon Anggota Baru mendaftarkan diri melalui sistem dan mengisi biodata sesuai permintaan pengurus asosiasi, baru pengurus akan memvalidasi data para calon anggota baru dan akan secara otomatis calon anggota baru menjadi anggota dari Asosiasi Program studi Informatika PGRI Jawa Timur. Daya yang sudah ada di sistem akan menjadi data baku pengelola untuk menjadi data penerapan program Kerja dalam kaintannya Tri dharma perguruan Tinggi (Pengajaran, Penelitian dan pengabdian Kepada Masyarakat).

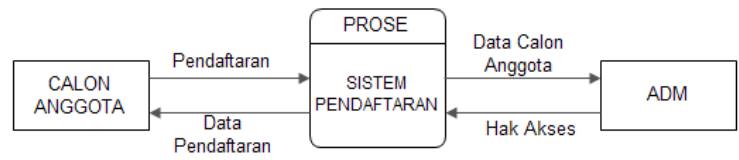

Gambar 1. Proses Alur Pendaftaran

Sistem Informasi Pendaftaran Online Anggota Asosiasi Program Studi Informatika Pgri Jawa Timur merupakan sistem yang dirancang untuk mempermudah para calon anggota baru untuk mendaftarkan diri sebagai bagian dari Asosiasi, dimana Program Studi Informatika diseluruh PGRI Jawa Timur bisa bersama-sama untuk memajukan keilmuannya..

Sistem ini merupakan langkah awal untuk memulai perbaikan organisasi dan dapat menjadi sumber informasi untuk para calon anggota baru.

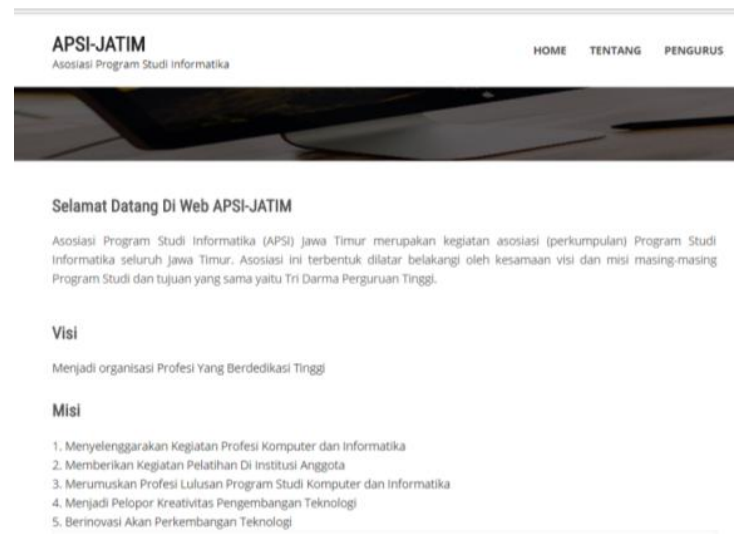

Gambar 2. Halaman Home

Anggota Asosiasi terekap dalam sistem dan dapat diketahui oleh anggota yang sudah tervalidasi oleh pengurus asosiasi. Daftar nama anggota akan mendapatkan id anggota dan krtu anggota akan di kirim di kampus masing-masing dosen yang mendaftarkan diri sebagai anggota asosiasi.

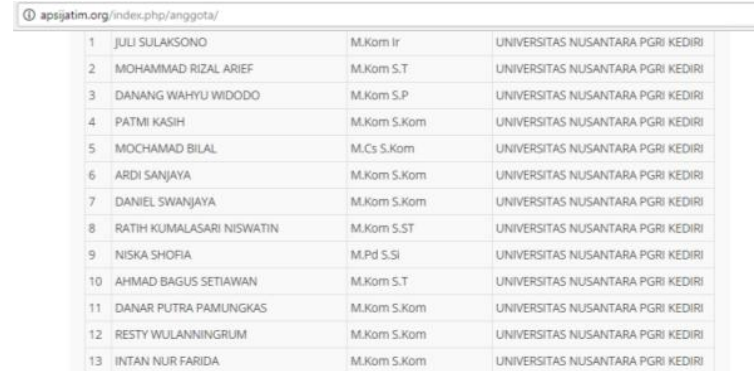

Gambar 3. Pendaftaran anggota

\section{KESIMPULAN}

Dari implementasi penelitian Sistem Informasi Pendaftaran Online Anggota Asosiasi Program Studi Informatika Pgri Jawa Timur dapat diberikan beberapa kesimpulan sebagai berikut:

a. Calon Anggota Asosiasi dapat mendaftaran diri melalui domain Asiasi.

b. Calon Anggota Akan mendapatkan konfirmasi, setelah di verifikasi oleh pengurus asosiasi.

c. Anggota baru dapat melihat anggota asiasi secara keseluruhan.

\section{PUSTAKA}

Judul bagian pustaka di atas tidak diberi nomor. For James A. O’brien, Pengantar Sistem Informasi Perspektif Bisnis dan Manajerial,Jakarta: Salemba Empat, 2005.

Jogiyanto, Sistem Teknologi Informasi, Yogyakarta: Andi, 2005

Pressman , Roger S, Rekayasa Perangkat Lunak Pendekatan Praktisi. Yogyakarta:Andi, 2013

Setiawan, Ahmad Bagus, Perencanaan Sistem Informasi Strategis E-Laundry Di Kota Kediri, Semnasteknomedia Online, 2016

Setiawan, Ahmad Bagus, Sistem Pendataan Santri Berdasarkan Tingkat Pendidikan di Pondok Pesantren Al-Ishlah Bandar Kidul Kota Kediri, Snatika 2017. 